This item was submitted to Loughborough's Research Repository by the author.

Items in Figshare are protected by copyright, with all rights reserved, unless otherwise indicated.

\title{
The gap between career management expectations and reality - empirical insights from the IT industry
}

PLEASE CITE THE PUBLISHED VERSION

https://doi.org/10.1007/s11612-018-0402-1

\section{PUBLISHER}

(C) Springer

\section{VERSION}

AM (Accepted Manuscript)

\section{PUBLISHER STATEMENT}

This work is made available according to the conditions of the Creative Commons Attribution-NonCommercialNoDerivatives 4.0 International (CC BY-NC-ND 4.0) licence. Full details of this licence are available at: https://creativecommons.org/licenses/by-nc-nd/4.0/

\section{LICENCE}

CC BY-NC-ND 4.0

\section{REPOSITORY RECORD}

Gubler, Martin, Crispin Coombs, and John Arnold. 2019. "The Gap Between Career Management Expectations and Reality - Empirical Insights from the IT Industry”. figshare. https://hdl.handle.net/2134/28384. 
Running head: Career management expectations and reality

\title{
The Gap between Career Management Expectations and Reality - Empirical Insights from the IT Industry
}

\author{
Martin Gubler ${ }^{\mathrm{a}}$ \\ Crispin Coombs ${ }^{b}$ \\ John Arnold ${ }^{\mathrm{b}}$ \\ ${ }^{a}$ Career Research Programme, Schwyz University of Teacher Education (Switzerland) \\ ${ }^{\mathrm{b}}$ School of Business and Economics, Loughborough University (UK) \\ Correspondence concerning this article should be addressed to: \\ Martin Gubler, Schwyz University of Teacher Education, Zaystrasse 42, CH-6410 Goldau, \\ Switzerland, Email: martin.gubler@phsz.ch
}


Career management expectations and reality

\begin{abstract}
The Information Technology (IT) industry has become an important economic factor in many Western countries, but it is well known for suffering from skills shortages and high turnover rates. Organizational career management (OCM) may help to attract new talent and reduce IT turnover by satisfying individuals' career needs. However, to date, little is known about what, exactly, IT professionals expect in terms of career-related support, and whether their expectations match with what IT organizations provide. This paper reports on a quantitative study that investigated what 1,686 IT professionals in Switzerland, Germany and the UK expected and what their employers provided in terms of OCM. Findings indicate that there are substantial mismatches between OCM 'supply' and 'demand'. The paper makes an important contribution by providing a more in-depth understanding of IT professionals' OCM preferences, leading to various practical implications for IT organizations and beyond.
\end{abstract}

Keywords: organizational career management, IT professionals, career support 
Career management expectations and reality

\section{Zusammenfassung}

Die IT-Branche ist in vielen westlichen Ländern zu einem wichtigen Wirtschaftsfaktor geworden, doch ist sie auch bekannt für Fachkräftemangel und hohe Fluktuationsraten der Arbeitnehmer. Personalentwicklung (PE) und gezielte Laufbahnförderung können dem entgegenwirken. Bis heute ist jedoch kaum bekannt, welche Art der Unterstützung ITFachleute bezüglich dieser Themen von ihren Arbeitgebern erwarten und welche Angebote ihnen tatsächlich zur Verfügung stehen. Dieser Artikel berichtet von einer quantitativen Studie, die PE-Erwartungen von 1686 IT-Fachleuten in der Schweiz, Deutschland und England untersuchte und deren Erwartungen mit den zur Verfügung gestellten Angeboten der Arbeitgeber verglich. Es zeigten sich dabei substantielle Abweichungen zwischen ,Angebot‘ und ,Nachfrage‘. Damit leistet dieser Artikel einen wichtigen Beitrag zu einem besseren Verständnis über PE und Laufbahnförderung von IT-Fachleuten. Daraus lassen sich etliche praktische Implikationen ableiten - für IT-Firmen und darüber hinaus.

Keywords: Personalentwicklung, IT-Fachleute, Laufbahnförderung 
Career management expectations and reality

The Gap between Career Management Expectations and Reality -

Empirical Insights from the IT Industry

Over the course of a few decades, the Information Technology (IT) industry has become an important economic factor in many industrialized countries. For example, in Switzerland the IT industry accounts for about $4.5 \%$ of the national Gross Domestic Product (GDP) (Bundesamt für Statistik, 2017). However, the IT industry across Europe is well known for suffering from skills shortages (Scholarios et al., 2008). As a result, it is expected that by 2020 tens of thousands of IT job openings in Germany and Switzerland will lack adequately qualified IT professionals (Braun \& Gmünder, 2012; Bundesagentur für Arbeit, 2017). In addition, voluntary turnover is particularly high in the IT industry compared to the general workforce (Henneberger \& Sousa-Poza, 2002). This exacerbates the situation for IT organizations, leading to various negative effects. For example, the lack of IT professionals can cause projects to fail (Coombs, 2009) and it can create serious problems regarding customer satisfaction (Scholarios et al., 2008). Therefore, it has been argued that in the IT industry "strategies that retain key people will [become] at least as important as those that attract new talent" (Murphy, 2009, p. 19).

Several studies (e.g., Agarwal \& Ferratt, 2002) have suggested that IT professionals' turnover can be reduced if individuals' career desires and needs can be satisfied through organizational career management (OCM). OCM is the process of an organization carrying out activities that are relevant to the career development of its employees (Baruch \& Peiperl, 2000). OCM practices have a close relationship with organizational career planning and its management, such as performance appraisals, formal mentoring or training (Baruch \& Peiperl, 2000). Unfortunately, research indicates that there are major deficiencies in OCM in IT with many companies only implementing very narrow and limited OCM tools (Scholarios et al., 2008). Yet, inadequate or bad OCM may increase turnover (Cappelli, 2001), whereas effectively implemented OCM tools make it possible to create a 'virtuous circle' where career 
Career management expectations and reality

management by individuals and organizations build constructively on each other (Sturges,

Guest, Conway, \& Mackenzie Davey, 2002). Thus, IT organizations are increasingly forced to update and refine the OCM tools they adopt to develop and retain their employees. However, to date little is known about what IT professionals expect in terms of OCM to support their own careers. This means that the planning and implementation of OCM in companies is often built on assumptions, potentially leading to a mismatch between 'supply' and 'demand'

Based on a large sample of IT professionals in Switzerland, Germany and the UK, this paper presents empirical insights into IT professionals' OCM-related expectations and how these expectations match with what organizations actually provide. Given the potential benefits of OCM and its importance in the IT industry, answers to these questions not only provide new academic knowledge but also lead to important practical recommendations for IT organizations. The results may also provide helpful new insights to support OCM in other industries, as the IT industry is thought to be prototypical for more general career-related trends (e.g., Gubler, Arnold, \& Coombs, 2014). For example, IT professionals have long been known for their high mobility and turnover rates (e.g., Saxenian, 1996) in volatile labour markets (Scholarios et al., 2008).

In the following sections, we first present the relevant theoretical background on IT professionals and OCM tools, leading to our research questions. We then describe our method and present the results, which leads to a discussion of our findings, the practical implications and the limitations of this study.

\section{Changing Career Paths, Skill Requirements and the Role of OCM}

Innovation in IT is considered a key trigger for a wide range of economic and societal changes. For example, digitalization may substantially change organizational processes and individual job profiles in various industries, such as in healthcare (e.g., Gastaldi \& Corso, 2012). Yet, the IT industry itself is also directly affected by these technological innovations. IT professionals' work environment, their roles, responsibilities, customers, and the 
Career management expectations and reality

knowledge required are often no longer the same as they were only a few years ago. As a consequence, many individual career paths in IT have also drastically changed. In the early days of IT, there was a limited set of roles with very distinct and typical career paths (Kraft, 1977). Nowadays, such predefined career paths can hardly be found in organizations. Due to the fast growth of the IT industry, there is a much broader range of people working in manifold roles (Niederman, Moore, \& Yager, 1999). The variety of careers in IT and the specialization therein have grown substantially as well, all of which has resulted in increasingly flexible and unpredictable career paths in this industry (Loogma, Ümarik, \& Vilu, 2004). Furthermore, the rapid technological development in IT constantly requires the acquisition of new skills (e.g., mastering a particular programming language) and makes old ones obsolete. This increases pressure at work, for example, for programmers who lack the latest skills required (Scholarios et al., 2008). Thus, OCM is crucial both for IT professionals as well as for their employers.

The main purposes of OCM are to ensure that the organization has a sufficient number of adequately trained staff for current and future needs, to improve employee productivity and to retain employees with high performance or critical skills (Creed \& Hood, 2009). The basic underlying assumption is that OCM (e.g., training activities) will positively affect peoplerelated outcomes (e.g., attitudes, motivation). OCM tools have been reported to increase productivity and satisfaction among IT professionals (e.g., Ferratt \& Short, 1988), as well as to reduce turnover rates (e.g., Agarwal \& Ferratt, 2002). In order to be effective, OCM requires a systematic approach that can respond to the needs of the individual as well as integrate organizational requirements (Lips-Wiersma \& Hall, 2007).

One recurring argument against providing extensive OCM is that it may equip welleducated and more flexible employees to look for new jobs and leave their current employers (e.g., Scholarios et al., 2008). This is a dilemma, especially for organizations that rely on highly qualified employees, even though newly acquired skills may not be as portable as often 
Career management expectations and reality

feared by managers (O'Mahony \& Bechky, 2006). However, anecdotal evidence from IT companies in Switzerland suggests that the provision of OCM can — in contrast—-serve as a key attractor and retention tool for highly skilled professionals in a labour market with a shortage of adequately trained specialists. For example, Zühlke Engineering AG (an international software and engineering company) invests $12 \%$ of its revenues in OCM, and each employee is granted 20 days per year that can be individually and freely dedicated to OCM-related activities. This makes Zühlke an attractive employer for highly qualified applicants. Turnover is low, and the company has steadily grown over the last decade, even in times of severely dry IT labour markets (www.zuehlke.com, Heer, 2008). Overall, however, it seems that the relevance of OCM is not yet fully acknowledged across the IT industry, even though IT organizations tend to spend more on OCM than companies in other industries (Colley, 2008). According to Scholarios et al. (2008), often only narrow and very limited OCM tools are in place, particularly among small and medium-sized IT enterprises.

In conclusion, IT organizations may be well advised to provide effective OCM. Yet, despite the generally accepted relevance of OCM for organizations and individuals, little is known about individual preferences for specific OCM tools and their availability in the context of the IT industry (e.g., Blessing White, 2007). This study aims to provide a better understanding of IT professionals' individual expectations regarding their careers and the corresponding organizational support, based on the following exploratory research questions:

RQ 1) Which OCM tools are regarded as most useful by IT professionals in Switzerland, Germany, and the UK?

RQ 2) Which OCM tools are most easily available to IT professionals in Switzerland, Germany, and the UK?

RQ 3) What differences, if any, can be observed between the perceived usefulness of OCM tools and their availability? 
Career management expectations and reality

\section{Study Design and Method}

\section{Design}

An online questionnaire was distributed to 3,817 IT professionals across 10 different organizations in Switzerland, Germany, and the UK as part of a wider study of career orientations of IT professionals in 2008. The final sample $(N=1,708)$ covered a broad range of different IT employment settings and roles. It comprised a variety of IT companies and IT departments in large non-IT organizations from various industries in the private and public sectors, ranging from small start-up companies to large multi-national corporate firms. Managers as well as non-managers in IT-related roles were surveyed, but IT contractors were excluded from the survey, as they were unlikely to have access to OCM tools. The survey was sent to potential participants directly by the Human Resource Management (HRM) department or the top management in each organization. As organizations did not know who participated and the research team was not supplied with any contact information of the participants, these were able to preserve their anonymity. The survey was provided in English, German and French.

\section{Measures}

For this study, 19 OCM tools were identified. The selection was based on HRM and IT literature (e.g., Agarwal \& Ferratt, 2002; Baruch \& Peiperl, 2000), as well as based on the authors' individual domains of expertise in (respectively) career research, IT career research, and being an IT OCM practitioner in a multi-national corporation. To ensure that the participants had a common understanding of all scale items, each OCM practice was briefly described in a help menu (see Table 1). The list was presented in random order to each participant to avoid potential response bias.

Respondents were first asked to select the five OCM tools that they felt would be most useful to them, regardless of the actual availability of these practices. Then, they had to select those five OCM tools that they thought were most easily accessible to them, regardless of the 
Career management expectations and reality

perceived usefulness of these tools. The limit of five tools was chosen for two reasons. First, it should force respondents to make choices_ - rather than just ticking all the tools_-but still give them the option to indicate a variety of preferences. Second, this approach was also considered to be more realistic than giving a rating (e.g., on a 1-5 scale) to each OCM tool because in practice employees do not have time to participate in a large number of OCM interventions, even if available.

\section{Sample}

For the OCM analyses, 22 participants who had not indicated at least one OCM tool as either useful or available were excluded. This resulted in a sample size of $n=1,686$ for all subsequent analyses. The respondents were predominantly male (85.3\%), married (54.2\%) and had no children (51.8\%). Their average age was 39.8 years $(\mathrm{SD}=8.8)$. They had worked in IT for an average of 13.6 years $(\mathrm{SD}=8.2)$, had been with their current employer for 8.5 years $(\mathrm{SD}=7.8)$ and had held their current role for 3.5 years $(\mathrm{SD}=3.6)$. Swiss citizens accounted for $889(52.7 \%)$ of respondents, with UK at 333 (19.8\%), Germany 243 (14.4\%), others 173 $(10.3 \%)$ and $48(2.8 \%)$ unknown. The Swiss respondents were mainly from the Germanspeaking part of the country. Two thirds of these IT professionals $(63.5 \%)$ either held a Bachelor's, a Master's or a $\mathrm{PhD}$ degree. The respondents worked in a wide range of IT functions, of which the most widely represented were software development (27.9\%) and project management (14.3\%). Most of the respondents (86.8\%) worked full time. Lastly, 544 $(32.3 \%)$ of the respondents had at least one subordinate. Comprehensive data on the IT workforces are sparse for the three countries in this study. However, regarding gender, age and qualifications, our sample did not show any significant demographic differences compared with the overall population of IT professionals in each country (e.g., E-Skills UK, 2008). 
Career management expectations and reality

\section{Results}

As a first step, various types of frequencies were calculated for each of the 19 OCM tools, as shown in Table 1. In addition to the totals for usefulness and availability, a distinction was made between three groups of respondents: first, those who felt that a particular tool was both useful and available to them; second, respondents who thought a particular tool would be useful to them but did not rank that tool as one of their top five accessible OCM tools; and third, respondents who had access to a particular tool but did not list that tool as one of their five most useful OCM tools.

- Insert Table 1 -

Based on Table 1, the perceived usefulness of each tool was contrasted with its availability. Figure 1 provides that comparison, showing which tools were perceived as the most useful ones.

\section{- Insert Figure 1 -}

Overall, on-the-job learning opportunities were considered as the most useful OCM tool. Functional/technical skills training and personal development plans were rated as the next most useful tools. For all three of them, the perceived usefulness matched well with their availability. The fourth and fifth most frequently named tools, however, showed major gaps between perceived usefulness and availability. Clear criteria for advancement were considered to be highly useful but they were much less often available. Conversely, performance appraisals appeared to be widely available but respondents rated their usefulness much lower. Outplacement, online communities and career workshops were ranked as the three least useful OCM tools. It was noteworthy that informal feedback and informal career discussions were both considered to be more useful than feedback and career discussions in pre-defined, formal settings. Also, it appeared that functional/technical skills training was regarded as much more useful than interpersonal skills training. 
Career management expectations and reality

In Figure 2, rather than looking at the totals of perceived OCM usefulness and availability, only the gap between them is displayed. A negative value indicates that a tool was perceived as more useful than available. Vice versa, positive values indicate that the availability of a tool was higher than its perceived usefulness.

\section{- Insert Figure 2 -}

The largest gap between high perceived usefulness and low availability emerged with regard to clear criteria for advancement. Generally, it appeared that OCM tools that can easily be standardized, such as performance appraisals, formal feedback or internal job markets, were perceived as clearly more available than useful. In contrast, tools such as career counselling, career coaching or mentoring, all of which provide highly individualized support but also require individualized solutions, showed distinct differences between relatively high perceived usefulness and relatively low availability.

However, the two figures above do not indicate whether the individuals who felt a particular tool was useful to them actually had access to it. Likewise, neither of them indicates whether the individuals who had access to a particular tool were also those who felt that it was useful. Therefore, Figure 3 does not compare frequencies of perceived usefulness between the 19 OCM tools. Instead, among those participants who selected a particular tool, a distinction is made between those who felt this tool was both useful and available to them, and those who thought it was useful but not among their five most accessible tools.

\section{- Insert Figure 3 -}

Figure 3 shows that performance appraisals, on-the-job learning opportunities, as well as formal and informal feedback, were all considered as useful and available by at least $50 \%$ of the respondents who selected these OCM tools among their five most useful ones. Remarkably for IT professionals, technical skills training appeared not to be available (as one of the top five tools) to slightly more than half of the respondents who indicated that it would be useful to them. This picture was even more accentuated for OCM tools that provide highly 
Career management expectations and reality

individualized support, such as career counselling, coaching, outplacement, or mentoring. Those who felt such a tool would be useful to them without having access to it far outnumbered those who thought it was both useful and available. A similar situation could be observed for those who felt clear criteria for advancement would be useful to them. In brief, the majority of the respondents did not seem to have the tools available that they considered useful.

From an HRM perspective, however, the key question is whether the tools provided are actually perceived as useful, which is addressed in Figure 4. It shows the ratio between those who indicated that a particular tool was both available and useful, and those who had access to that tool without considering it as one of their five most useful tools.

\section{- Insert Figure 4 -}

Of all 19 tools, only on-the-job learning opportunities and functional/technical skills training were perceived as useful by a majority of those who had access to them. In other words, most OCM tools did not seem to be perceived as useful by those employees who had access to them. When comparing Figure 3 and Figure 4, there seemed to be major gaps for most tools regarding the perceptions of those with access to a particular tool and those without access. For example, mentoring was available (as one of the top five tools) to only about $12 \%$ of those respondents who thought it would be useful. However, almost $75 \%$ of those who indicated that they had access to mentoring did not feel it was one of their five most useful tools.

In sum, in response to RQ1, IT professionals perceived on-the job learning opportunities, functional/technical skills training and personal development plans as the three most useful OCM tools. In terms of RQ2, performance appraisals, on-the-job learning opportunities and informal feedback were the three most widely available OCM tools. Regarding RQ3, one key finding was that individuals who had access to a particular tool mostly did not perceive it as useful. Further, the gap between availability and perceived 
Career management expectations and reality

usefulness was biggest for standardized tools like performance appraisals. Such tools appeared to be widely available but their perceived usefulness tended to be low. With regard to more individualized tools, such as career counselling, the situation was exactly the reverse. The perceived usefulness of such tools tended to be clearly higher than their availability.

\section{Discussion}

Based on a large sample of IT professionals from Switzerland, Germany, and the UK, this study addressed the current lack of knowledge regarding the career-related support highly qualified employees would find useful, and how this corresponds with the OCM tools they are actually provided. The results highlight various notable aspects.

First, the largest gap between high perceived usefulness and low availability emerged with regard to clear criteria for advancement. This implies that the organizations only partially met the respondents' expectations regarding clarity of their future career paths, as participants would have expected much more guidance and structure for their career planning. This is in contrast to a frequent assumption in the general careers literature, where IT professionals' careers have often been described as highly agentic, flexible and free of organizational constraints (e.g., Saxenian, 1996). The results in this study caution against underestimating the value IT professionals attribute to OCM. At least for our sample, it seems as if organizations still play (and are expected to play) an important role in providing career support for individuals.

Second, in line with Blessing White (2007), one key finding was the notable gap between the wide availability and the low perceived usefulness of tools that can easily be standardized. The reverse was found for tools that can be well tailored to individuals' requirements. Also, informal approaches were perceived as more useful than formal processes. Hence, individuals tended to find tools more useful that allow them to address their needs as timely and as individually as possible. Standardized tools may be straightforward to implement in organizations, and they arguably provide a reasonable degree of fairness to 
Career management expectations and reality

employees because everybody is treated equally. However, the findings in this study imply that, from an employee's point of view, OCM needs to be much more tailored to individual needs.

A third notable finding was that individuals with access to a particular tool mainly did not seem to find it useful. Conversely, individuals without access to that tool appeared to regard it as highly useful. To some degree, this discrepancy may have been caused by respondents' wishful thinking ('the grass is always greener on the other side'). Individuals may simply have believed that tools unavailable to them could provide them with more substantial and effective support for their careers, whereas actually available tools may tend to lack such idealization. Further, given that various authors (e.g., Doyle, 2000) have highlighted the importance of a careful implementation of OCM tools, one may argue that the tools could have been implemented badly in the participating organizations and that more carefully applied tools might have improved the results. Based on the data in this study it is impossible to assess how well the tools were implemented in each organization. Nevertheless, it seems rather improbable that badly implemented tools alone would fully explain these findings, given the clear and consistent results across all organizations.

In combination with the above-mentioned gap between standardized and individualized tools, psychological contracts (i.e., mutual expectations between employer and employee beyond the legal contract, Rousseau, 1990) may offer an additional explanation for this finding. Inkson and King (2011, p. 43) described how "unspecified and implicit expectations $[\ldots]$ lead to a degree of indeterminacy" between employers and employees, and they argued that individual clarifications of psychological contracts may be needed to minimize potential conflicts. It seems plausible that discussions between employers and employees also ought to cover questions regarding OCM because these aspects are "centrally concerned with [an individual's] future working life" (Hirsh, Jackson, \& Kidd, 2001, p. 37). Yet, many organizations tend to apply standardized tools, and the availability of OCM tools is 
Career management expectations and reality

rarely discussed at an individual level. Thus, a lack of involvement in the decision process regarding individual career support can arguably lead to unmet expectations of employees and, ultimately, to a reduced perceived usefulness of the OCM tools provided.

\section{Practical Implications}

Although understanding what kind of career support employees require is paramount, the findings in this study suggest that the provision of targeted OCM tools may need improvement in many organizations. This leads to various practical implications that can help organizations to strengthen their OCM.

First, in line with Baruch (2009), no generally applicable "best practice" may be available for organizations. That is, HRM representatives must not simply try to apply a set of OCM tools that appears to work in a different organization. Rather, they should define their own set of OCM tools, matching the specific needs and requirements in their organization. Thus, a thorough understanding of the specific organizational requirements is key, and such in-depth knowledge crucially depends on a thorough understanding of individual expectations. Not surprisingly, therefore, the HRM representatives of all participating organizations considered the results of this study as highly relevant for their future OCM planning.

Second, HRM managers should not expect that employees find all the OCM tools provided in the organization useful. To increase the match between organizational OCM 'supply' and employees' OCM 'demand', taking the individual perspective into account is crucial. In other words, as part of a wider discussion regarding mutual expectations and obligations, individuals should be given more decision power when it comes to selecting their OCM tools. Valuing employees as individuals, and addressing their individual requirements, sounds like a small thing; yet, if taken seriously, it may require substantial changes to existing HRM processes. Particularly in large organizations, taking an individualized approach to OCM may challenge the prevailing corporate culture. However, the situation displayed in 
Career management expectations and reality

Figure 4 is simply not sustainable for any organization; the amount of wasted time, money and engagement is just too large. Thus, the potential benefits of individually targeted, positively perceived career support should more than outweigh the additional efforts needed to redefine existing processes and the additional time required for more intense discussions with employees.

More individualization in OCM would not only reduce the 'grass is always greener on the other side' effect. It helps organizations to become more attractive employers in a dry labour market (Heer, 2008), and taking individual perspectives into account can increase employees' overall motivation, well-being and job satisfaction (e.g., Hall, Briscoe, Dickmann, \& Mayrhofer, 2012). As a result, OCM tools may be applied more (cost-)effectively and turnover rates may be reduced. Hence, a better understanding of individual preferences regarding career support can also lead to a more effective usage of the OCM budget. In addition, such individualized approaches would support a proactive and systematic integration of career-related concerns into organizational change management, which contributes to increased employee buy-in in organizational change processes (Lips-Wiersma \& Hall, 2007). Clearly, the degree to which such individualized OCM approaches can be implemented will vary between organizations. Nevertheless, there are arguably many more options for organizations to take individual perspectives into account than commonly believed. For example, as shown in the results, simply providing (more) informal opportunities to address career-related discussions and provide feedback would help. Overall, thus, asking employees about their preferences is an easy but highly useful first step worth taking towards more effective OCM.

\section{Limitations and Future Research}

Although this study is built on a large, multi-national and multi-organizational sample, it focuses on a highly educated and predominantly male sample from one single occupation in three countries in Europe. Thus, even though the IT industry can be regarded as a bellwether 
Career management expectations and reality

for other industries, generalization of the results may be limited to similar settings (e.g., regarding gender, education, or occupation). From a methodological point of view, the crosssectional data collection does not allow the establishment of causal relationships. Further, the limitation to five selectable OCM tools might well have led to the omission of some tools individuals would also think were available and/or useful. Moreover, we acknowledge that the survey only collected dichotomous (rather than Likert-scale-based) self-reported assessments of the participants, and a corresponding assessment by HR professionals or line managers was not included. Lastly, as the degree to which employees find training helpful is not necessarily related to their actual learning outcomes (e.g., Bates, 2004), the perceived usefulness of the OCM tools needs to be interpreted cautiously.

For future research, it would be valuable to explore OCM preferences of employees from other occupational backgrounds. Also, a key theme to explore further is why and/or when individuals do not value the OCM tools they have access to. These analyses should be expanded, exploring relationships between OCM tools and other relevant variables (e.g., age, gender, job role). Future research may also benefit from giving respondents the opportunity to express freely which tools they would find most useful, rather than presenting them a predefined list of tools, resulting in a more nuanced, more individualized picture of OCM tool preferences and allowing researchers to investigate the most recent trends in OCM. This would provide organizations with highly relevant additional input for refining their OCM processes, helping them to address skills shortage and high turnover rates more effectively.

\section{References}

Agarwal, R., \& Ferratt, T. W. (2002). Enduring practices for managing IT professionals. Communications of the ACM, 45(9), 73-79. doi:10.1145/567498.567502

Baruch, Y. (2009). Career planning and management interventions from the organisational perspective. In A. Collin \& W. Patton (Eds.), Vocational psychological and organisational perspectives on career (pp. 131-145). Rotterdam: Sense Publishers.

Baruch, Y., \& Peiperl, M. A. (2000). Career management practices: An empirical survey and implications. Human Resource Management, 39(4), 347-366. doi:10.1002/1099$050 X(200024)$ 
Bates, R. (2004). A critical analysis of evaluation practice: The Kirkpatrick model and the principle of beneficence. Evaluation and Program Planning, 27(3), 341-347. doi:10.1016/j.evalprogplan.2004.04.011

Blessing White. (2007). State of the career report 2007. Retrieved from Princeton:

Braun, N., \& Gmünder, M. (2012). ICT-Fachkräftesituation - Bildungsbedarfsprognose 2020. Retrieved from Bern: http://www.pub.arbeitsagentur.de/hst/services/statistik/000000/html/start/monat $/$ aktuel $1 . \mathrm{pdf}$

Bundesagentur für Arbeit. (2017). IT Fachleute. Retrieved from Nürnberg: http://www.pub.arbeitsagentur.de/hst/services/statistik/000000/html/start/monat/aktuel $1 . p d f$

Bundesamt für Statistik. (2017). IKT-Sektor Wertschöpfung. Retrieved from https://www.bfs.admin.ch/bfs/de/home/statistiken/kultur-medieninformationsgesellschaft-sport/informationsgesellschaft/gesamtindikatoren/iktsektor.html

Cappelli, P. (2001). Why is it so hard to find information technology workers? Organizational Dynamics, 30(2), 87-99. doi:10.1016/S0090-2616(01)00045-6

Colley, J. (2008). Managing both careers and risks. Network Security, 2008(5), 7-9.

Coombs, C. (2009). Improving retention strategies for IT professionals working in the public sector. Information \& Management, 46(4), 233-240. doi:10.1016/j.im.2009.02.004

Creed, P., \& Hood, M. (2009). Career development, planning and management from the organisational perspective. In A. Collin \& W. Patton (Eds.), Vocational psychological and organisational perspectives on career (pp. 41-62). Rotterdam: Sense Publishers.

Doyle, M. (2000). Managing careers in organisations. In A. Collin \& R. A. Young (Eds.), The future of career (pp. 228-242). Cambridge: Cambridge University Press.

E-Skills UK. (2008). Technology counts: IT \& Telecoms insights 2008. Retrieved from London:

Ferratt, T. W., \& Short, L. E. (1988). Are information systems people different? An investigation of how they are and should be managed. MIS Quarterly, 12(3), 427-443.

Gastaldi, L., \& Corso, M. (2012). Smart healthcare digitalization: Using ICT to effectively balance exploration and exploitation within hospitals. International Journal of Engineering Business Management, 4, 1-13. doi:10.5772/51643

Gubler, M., Arnold, J., \& Coombs, C. (2014). Organizational boundaries and beyond: A new look at the components of a Boundaryless Career Orientation. Career Development International, 19(6), 641-667. doi:10.1108/CDI-11-2013-0143

Hall, D. T., Briscoe, J. P., Dickmann, M., \& Mayrhofer, W. (2012). Implications for the management of people and organizations. In J. P. Briscoe, D. T. Hall, \& W. Mayrhofer (Eds.), Careers around the world: Individual and contextual perspectives (pp. 166-186). New York: Routledge.

Heer, A. (2008). Unberührt vom Mangel an IT-Spezialisten. Retrieved from http://www.computerworld.ch/aktuell/itservices/44668/index.html

Henneberger, F., \& Sousa-Poza, A. (2002). Eine empirische Analyse von Stellenwechseln in der schweizerischen Telekommunikations- und Informatikbranche. Retrieved from St. Gallen: http://www.faa.unisg.ch/publikationen/diskussionspapiere/dp81.pdf

Hirsh, W., Jackson, C., \& Kidd, J. M. (2001). Straight talking: Effective career discussions at work. Retrieved from Cambridge:

Inkson, K., \& King, Z. (2011). Contested terrain in careers: A psychological contract model. Human Relations, 64(1), 37-57. doi:10.1177/0018726710384289

Kraft, P. (1977). Programmers and managers - The routinization of computer programming in the United States. New York: Springer-Verlag, Inc. 
Lips-Wiersma, M., \& Hall, D. T. (2007). Organizational career development is not dead: A case study on managing the new career during organizational change. Journal of Organizational Behavior, 28(6), 771-792. doi:10.1002/job.446

Loogma, K., Ümarik, M., \& Vilu, R. (2004). Identification-flexibility dilemma of IT specialists. Career Development International, 9(3), 323-348. doi:10.1108/13620430410535878

Murphy, P. (2009). Global workforce planning through 2016: How population shifts will affect the supply of IT skills. Retrieved from Cambridge, MA:

Niederman, F., Moore, J. E., \& Yager, S. E. (1999). A view from the SIGCPR conference: what have we learned in this decade? ACM SIGCPR Computer Personnel, 20(4), 7589.

O'Mahony, S., \& Bechky, B. A. (2006). Stretchwork: Managing the career progression paradox in external labor markets. Academy of Management Journal, 49(5), 918-941.

Rousseau, D. M. (1990). New hire perceptions of their own and their employer's obligations: a study of psychological contracts Journal of Organizational Behavior, 11(5), 389400.

Saxenian, A. (1996). Beyond boundaries: Open labor markets and learning in Silicon Valley. In M. B. Arthur \& D. M. Rousseau (Eds.), The boundaryless career: A new employment principle for a new organizational era (pp. 23-39). New York: Oxford University Press.

Scholarios, D., Van der Heijden, B. I. J. M., Van der Schoot, E., Bozionelos, N., Epitropaki, O., Jedrzejowicz, P., . . V Van der Heijde, C. M. (2008). Employability and the psychological contract in European ICT sector SMEs. International Journal of Human Resource Management, 19(6), 1035-1055. doi:10.1080/09585190802051337

Sturges, J., Guest, D., Conway, N., \& Mackenzie Davey, K. (2002). A longitudinal study of the relationship between career management and organizational commitment among graduates in the first ten years at work. Journal of Organizational Behavior, 23, 731748. doi:10.1002/job. 164 


\section{Career management expectations and reality}

Table 1: OCM tools - availability and usefulness

\begin{tabular}{|c|c|c|c|c|c|}
\hline \multirow[b]{2}{*}{ OCM tools and descriptions } & \multicolumn{5}{|c|}{ Tool is... } \\
\hline & $\begin{array}{l}\text { useful } \\
\text { (total) }\end{array}$ & $\begin{array}{l}\text { available } \\
\text { (total) }\end{array}$ & $\begin{array}{l}\text { useful, and } \\
\text { available }\end{array}$ & $\begin{array}{c}\text { useful, but } \\
\text { not availa- } \\
\text { ble* }\end{array}$ & $\begin{array}{l}\text { not } \\
\text { useful**, } \\
\text { but } \\
\text { available }\end{array}$ \\
\hline $\begin{array}{l}\text { Career coaching } \\
\text { (e.g., individual coach for developing certain skills) }\end{array}$ & 507 & 89 & 34 & 473 & 55 \\
\hline $\begin{array}{l}\text { Career counselling } \\
\text { (e.g., option to get individual advice on personal career } \\
\text { development) }\end{array}$ & 359 & 84 & 18 & 341 & 66 \\
\hline $\begin{array}{l}\text { Career workshops } \\
\text { (e.g., sessions about self-management) }\end{array}$ & 175 & 44 & 10 & 165 & 34 \\
\hline $\begin{array}{l}\text { Clear criteria for advancement } \\
\text { (e.g., transparent and freely accessible definitions of } \\
\text { promotion criteria) }\end{array}$ & 595 & 141 & 56 & 539 & 85 \\
\hline $\begin{array}{l}\text { Clear description of career paths and job levels } \\
\text { (e.g., transparent and freely accessible descriptions of } \\
\text { internal IT career paths) }\end{array}$ & 371 & 273 & 63 & 308 & 210 \\
\hline $\begin{array}{l}\text { Formal career discussions } \\
\text { (e.g., mid-year and year-end discussions with line manager) }\end{array}$ & 274 & 350 & 74 & 200 & 276 \\
\hline $\begin{array}{l}\text { Formal feedback } \\
\text { (e.g., regular } 360^{\circ} \text { feedback from managers, peers, clients } \\
\text { and team members) }\end{array}$ & 300 & 661 & 153 & 147 & 508 \\
\hline $\begin{array}{l}\text { Functional/technical skills training } \\
\text { (e.g., course on a programming language or a hardware } \\
\text { component) }\end{array}$ & 754 & 680 & 364 & 390 & 316 \\
\hline $\begin{array}{l}\text { Informal career discussions } \\
\text { (e.g., option to discuss career issues outside the formal mid- } \\
\text { year and year-end review) }\end{array}$ & 344 & 412 & 116 & 228 & 296 \\
\hline $\begin{array}{l}\text { Informal feedback } \\
\text { (e.g., spontaneous praise or criticism from managers, peers, } \\
\text { clients or team members) }\end{array}$ & 531 & 745 & 268 & 263 & 477 \\
\hline $\begin{array}{l}\text { Interpersonal skills training } \\
\text { (e.g., course on conflict-solving) }\end{array}$ & 392 & 268 & 79 & 313 & 189 \\
\hline $\begin{array}{l}\text { Mentoring programme } \\
\text { (e.g., option to be assigned to an internal mentor or to } \\
\text { become a mentor oneself) }\end{array}$ & 452 & 208 & 56 & 396 & 152 \\
\hline $\begin{array}{l}\text { Online networking/communities } \\
\text { (e.g., option to discuss career issues online with a group of } \\
\text { IT professionals in a similar position or with similar } \\
\text { interests) }\end{array}$ & 149 & 272 & 59 & 90 & 213 \\
\hline $\begin{array}{l}\text { On-the-job learning opportunities } \\
\text { (e.g., opportunity to develop new skills through active } \\
\text { participation in a new project) }\end{array}$ & 939 & 823 & 531 & 408 & 292 \\
\hline $\begin{array}{l}\text { Outplacement } \\
\text { (e.g., support to find a new position outside the current } \\
\text { organization) }\end{array}$ & 94 & 47 & 6 & 88 & 41 \\
\hline $\begin{array}{l}\text { Performance appraisal } \\
\text { (e.g., yearly discussion with manager about individual } \\
\text { performance and goal achievement) }\end{array}$ & 580 & 1,167 & 440 & 140 & 727 \\
\hline $\begin{array}{l}\text { Personal development plans } \\
\text { (e.g., yearly revised plan on personal development } \\
\text { activities) }\end{array}$ & 733 & 673 & 295 & 438 & 378 \\
\hline $\begin{array}{l}\text { Temporary assignments/secondments } \\
\text { (e.g., international assignment or job rotation to another } \\
\text { function) }\end{array}$ & 350 & 182 & 44 & 306 & 138 \\
\hline $\begin{array}{l}\text { Transparent internal job market } \\
\text { (e.g., option to apply for all internally available positions) }\end{array}$ & 420 & 654 & 171 & 249 & 483 \\
\hline
\end{tabular}

Note: $n=1,686$; numbers indicate number of responses; multiple answers were possible; *: tool not listed as one of the five most accessible OCM tools; **: tool not listed as one of the five most useful tools 


\section{Career management expectations and reality}

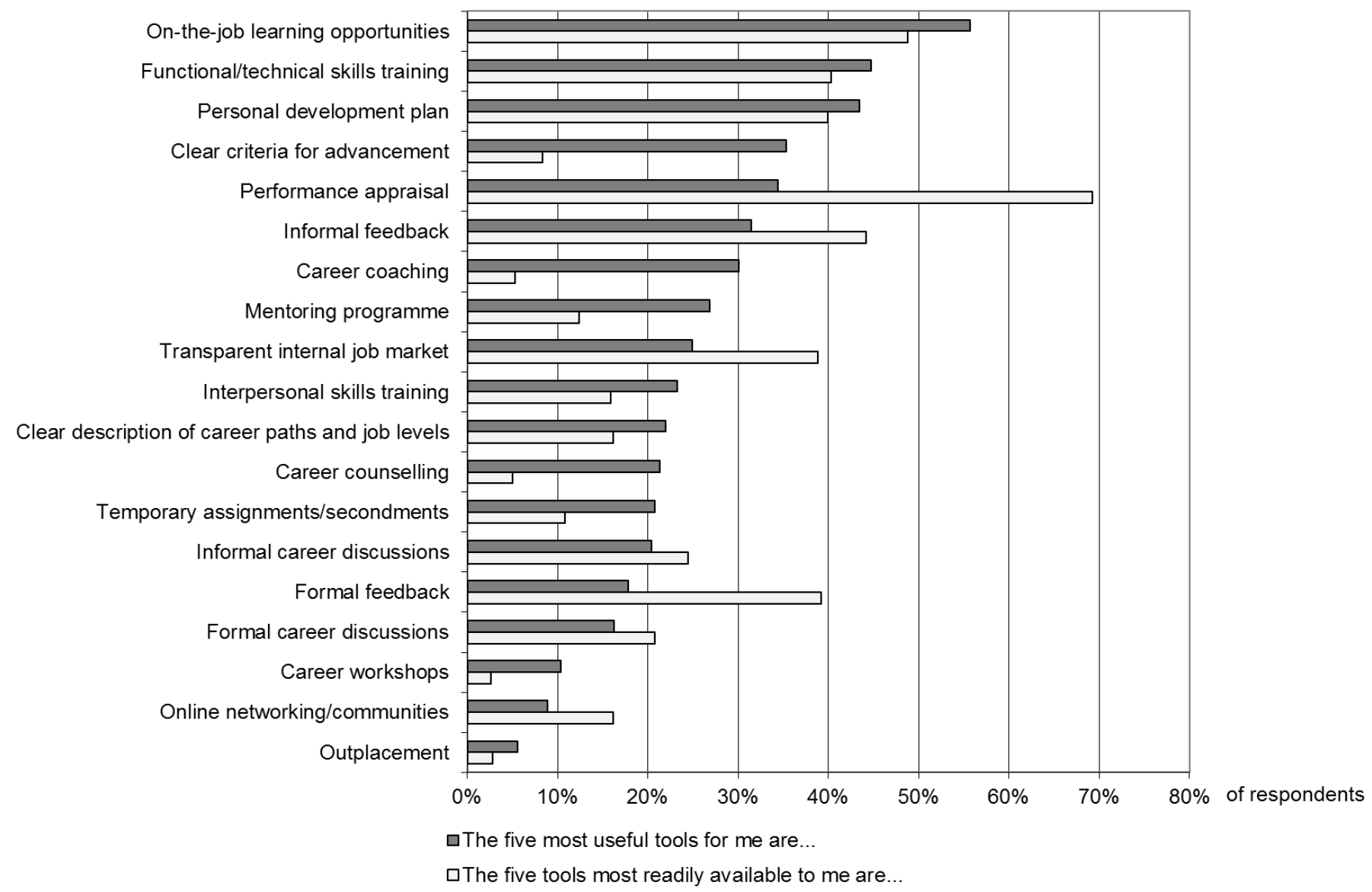

Figure 1: OCM tools - Frequencies, sorted based on perceived usefulness

Note: $n=1,686$; multiple answers were possible 
Career management expectations and reality

Performance appraisal Formal feedback

Transparent internal job market

Informal feedback

Online networking/communities

Formal career discussions

Informal career discussions

Outplacement

Personal development plan

Functional/technical skills training

Clear description of career paths and job levels

On-the-job learning opportunities

Interpersonal skills training

Career workshops

Temporary assignments/secondments

Mentoring programme

Career counselling

Career coaching

Clear criteria for advancement

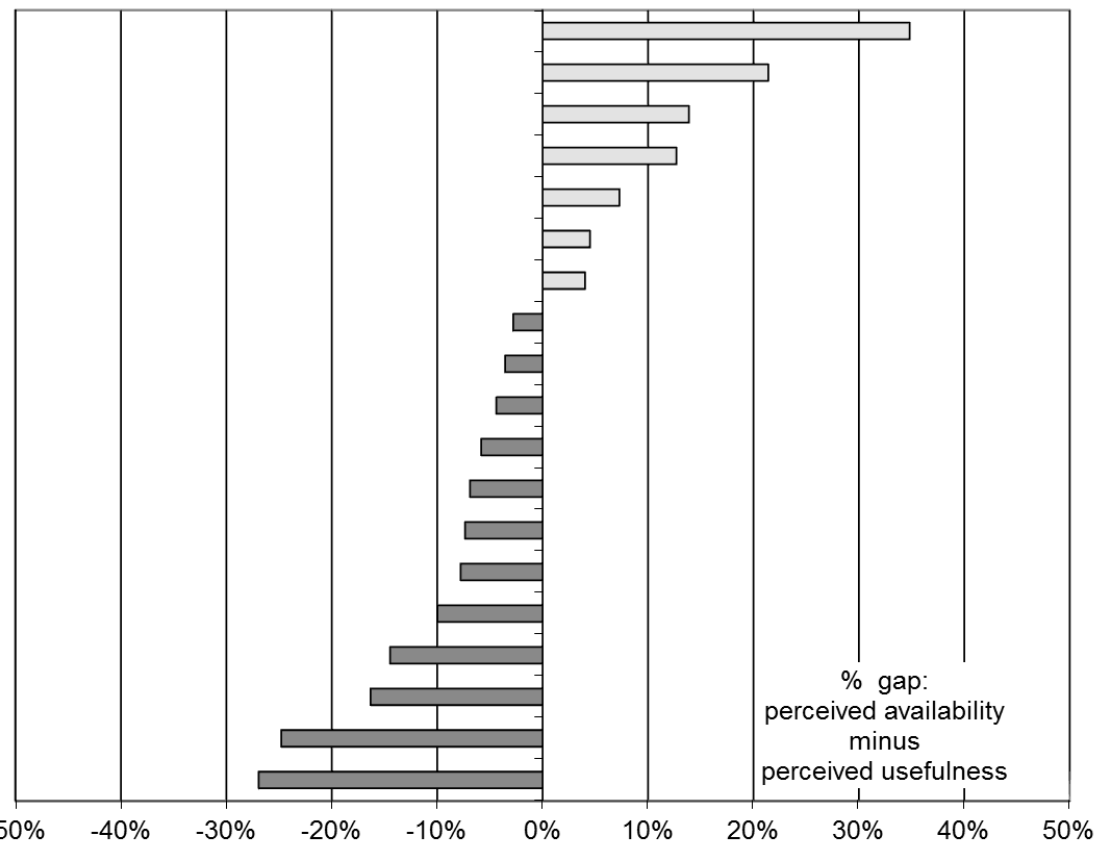

Figure 2: OCM tools - Differences between perceived usefulness and availability

Note: $n=1,686$; multiple answers were possible 


\section{Career management expectations and reality}

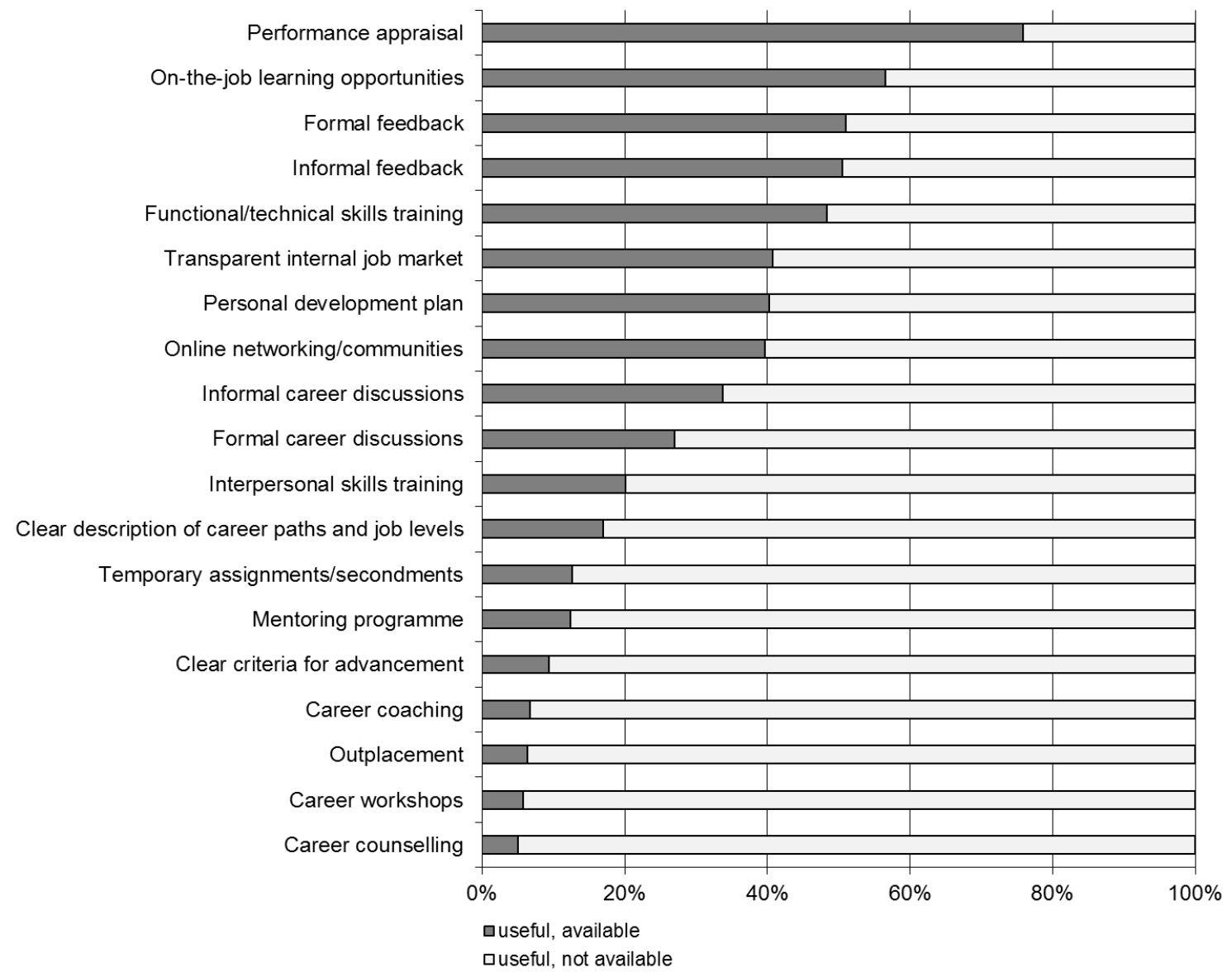

Figure 3: OCM tools - Perceived usefulness compared with availability

Note: Only comprises respondents who included a particular tool in the list of their five most useful tools 


\section{Career management expectations and reality}

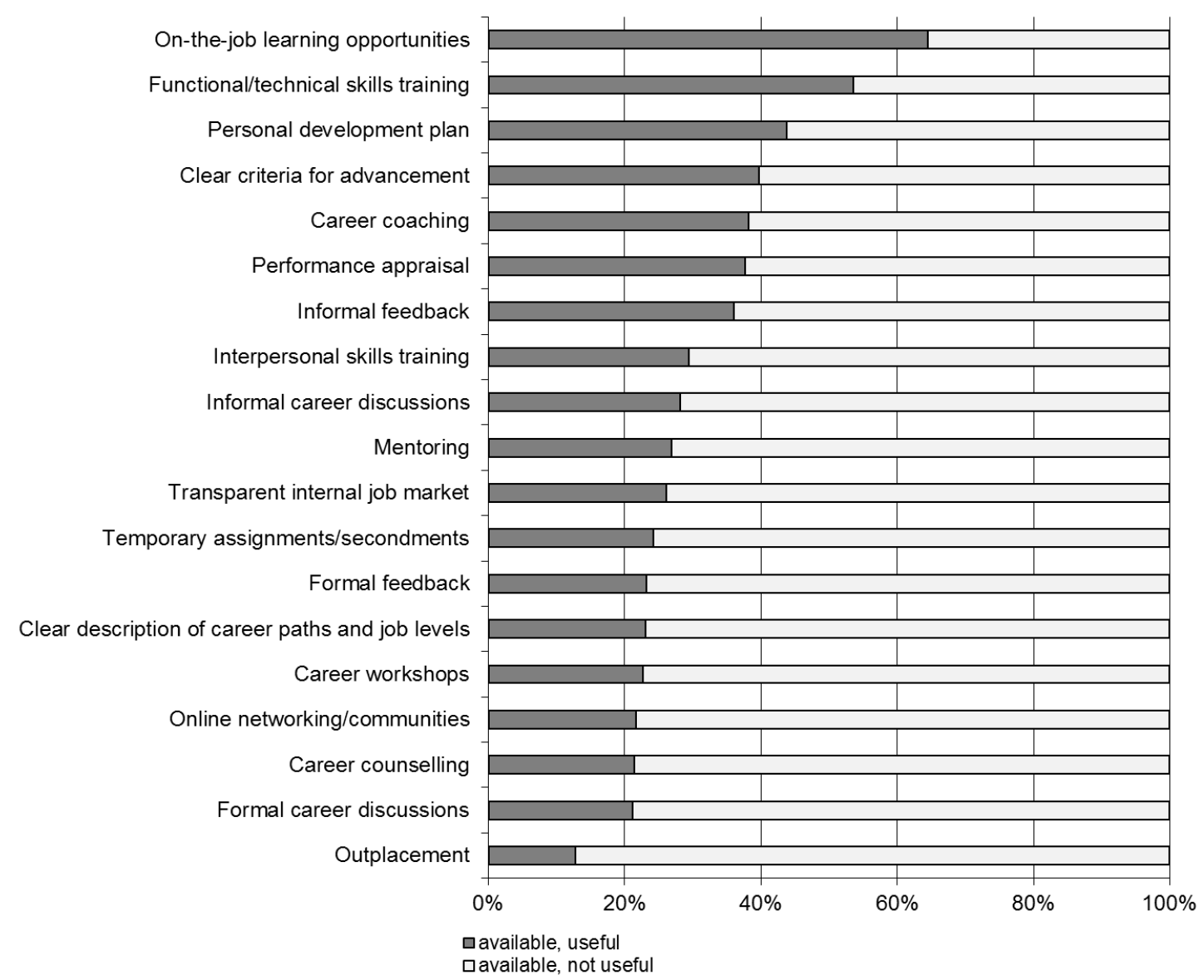

Figure 4: OCM tools - Availability compared with perceived usefulness

Note: Only comprises respondents who included a particular tool in the list of their five most available tools 